\title{
GURU BAHASA INDONESIA YANG PROFESIONAL
}

\author{
Dewi Syafrina \\ M. Bayu Firmansyah \\ Universitas Negeri Malang \\ dewirennaewii@gmail.com \\ firmansyahbayu970@gmail.com
}

\begin{abstract}
Abstrak
Masa depan pendidikan tertumpu pada guru dalam mendidik siswanya. Salah satu tolok ukur keberhasilan siswa dalam belajar yaitu keprofesionalan guru. Artikel ini bertujuan untuk memaparkan cara mewujudkan guru bahasa Indonesia yang profesional. Pemaparan ini berisi wawasan mengenai dua hal, yaitu (1) karakteristik guru bahasa Indonesia profesional yang dikaitkan dengan teori bahasa Chomsky dan (2) cara yang perlu dilakukan untuk mewujudkan guru yang profesional. Dua aspek dalam teori bahasa Chomsky - competence dan performance - menjadi tolok ukur dalam merinci karakteristik guru bahasa Indonesia yang profesional. Untuk mewujudkan guru bahasa Indonesia yang profesional, terdapat dua cara yang dapat diikuti oleh guru, yaitu pelatihan menjadi guru profesional dan seminar pendidikan. Melalui dua kegiatan tersebut guru dapat meningkatkan kompetensi diri sebagai guru profesional dan menerapkan arti pembelajaran sepanjang hayat (lifelong learning).
\end{abstract}

Kata kunci: guru profesional, pelatihan, seminar pendidikan, competence-performance

Profesional mengarah pada kepribadian seseorang yang menjalankan profesi sesuai dengan keahliannya; memiliki kemampuan dan berpegang teguh kepada nilai moral yang mendasari perbuatannya. Seperti yang disebutkan dalam Undang-Undang RI Nomor 14 tahun 2005 pasal 1 ayat 2, "Profesional adalah pekerjaan atau kegiatan yang dilakukan oleh seseorang dan menjadi sumber penghasilan kehidupan yang memerlukan keahlian, kemahiran atau kecakapan yang memenuhi standar mutu atau norma tertentu serta memerlukan pendidikan profesi."

Guru yang profesional berarti guru yang memiliki keterampilan atau keahlian yang diaplikasikan untuk mencapai tujuan profesi. Profesionalitas guru telah diatur dalam UndangUndang RI Nomor 14 tahun 2005, pasal 1 ayat 1, "Guru adalah pendidik profesional dengan tugas utama mendidik, mengajar, membimbing, mengarahkan, melatih, menilai dan mengevaluasi peserta didik pada pendidikan anak usia dini jalur pendidikan formal, pendidikan dasar, dan pendidikan menengah.”. Selanjutnya, keprofesionalan diatur pula melalui PP No. 19 tahun 2005 pasal 28 tentang profesionalitas guru yang setidaknya harus memenuhi persyaratan kompetensi, meliputi: kompetensi pedagogik, kompetensi kepribadian, kompetensi profesional, 
dan kompetensi sosial.

Pada Standar Nasional Pendidikan, penjelasan dari pasal 28 ayat 3, diuraikan tentang definisi empat kompetensi tersebut, yakni: (a) kompetensi pedagogik adalah kemampuan mengelola pembelajaran peserta didik yang meliputi pemahaman terhadap peserta didik, perancangan dan pelaksanaan pembelajaran, evaluasi hasil belajar, dan pengembangan peserta didik untuk mengaktualisasikan berbagai potensi yang dimilikinya; (b) kompetensi kepribadian merupakan kemampuan kepribadian yang mantap, stabil, dewasa, arif, dan berwibawa serta menjadi teladan bagi peserta didik dan berakhlak mulia; (c) kompetensi profesional adalah kemampuan penguasaan materi pembelajaran secara luas dan mendalam yang memungkinkannya membimbing peserta didik memenuhi standar kompetensi yang ditetapkan dalam Standar Nasional Pendidikan; dan (d) kompetensi sosial adalah kemampuan pendidik sebagai bagian dari masyarakat untuk berkomunikasi dan bergaul secara efektif dengan peserta didik, sesama pendidik, tenaga kependidikan, orangtua/wali peserta didik dan masyarakat sekitar. Berdasarkan empat kompetensi tersebut, kompetensi profesional merupakan kompetensi yang berkaitan dengan kinerja guru dalam mengampu mata pelajaran. Profesionalitas guru tersebut juga memiliki karakteristik sesuai dengan karakteristik mata pelajarannya.

Dalam Kurikulum 2013 edisi revisi tahun 2017 setidaknya dalam menyusun Rencana Pelaksanaan Pembelajaran (RPP) harus muncul empat hal, yaitu Penguatan Pendidikan Karakter (PPK), literasi, Creative, Critical Thinking, Communicative, dan Collaborative (4C), dan High Order Thinking Skill (HOTS) sehingga perlu kreatifitas guru dalam menyusunnya. Empat hal tersebut diintegrasikan, diperdalam, diperluas, dan sekaligus diselaraskan dengan berbagai program dan kegiatan pendidikan karakter yang sudah dilaksanakan sampai sekarang. Oleh karena itu, kompetensi profesional guru bahasa Indonesia perlu menjadi pertimbangan pertama dan utama dalam membimbing peserta didik agar dapat terampil memahami dan mengomunikasikan informasi.

Dalam hal ini kompetensi profesional tersebut mencakup lima subunsur: (a) menguasai teknik dan model belajar mengajar (termasuk penilaian hasil belajar), (b) mengutamakan standar profesi yang tinggi, (c) kreatif dan inovatif, (d) gemar belajar, membaca, dan menulis, dan (e) memiliki pengalaman mengajar. Namun sampai hari ini, kompetensi profesional tersebut belum tampak pada data uji kompetensi guru.

Berdasarkan berita di Republika, kompetensi guru bahasa di Indonesia masih rendah. 
Sebagai gambaran awal, setelah pelaksanaan Uji Kompetensi Awal (UKA) pada guru terkuak bahwa guru hanya menguasai $42,45 \%$ materi yang diajarkan kepada siswa sesuai jenjang dan bidang studinya. Presentase tersebut juga termasuk di dalamnya guru bahasa Indonesia yang belum menguasai mata pelajaran bahasa Indonesia. Selain itu, kompetensi guru di Jawa Tengah berada di jauh di bawah kriteria ideal. Balai Bahasa Provinsi Jawa Tengah menunjukkan hasil nilai ujian kompetensi guru bahasa Indonesia yang cukup rendah dengan nilai rata-rata hanya 47 dengan nilai 80 sebagai nilai ideal. Rendahnya nilai kompetensi guru bahasa Indonesia berdampak pada nilai Ujian Nasional (UN) siswa untuk mata pelajaran bahasa Indonesia.

Permasalahan lain muncul pada mata pelajaran bahasa Indonesia yang cenderung berfokus pada penguasaan materi, bukan pada kemampuan berbahasa siswa. Oleh karena itu, selain kompetensi yang harus dimiliki guru secara umum (profesional, pedagogik, kepribadian, sosial), guru bahasa juga harus memiliki kompetensi berbahasa yang terdiri atas empat keterampilan berbahasa, yaitu (a) menyimak, (b) berbicara, (c) membaca, dan (d) menulis. Berdasarkan empat keterampilan ini guru harus: (a) mampu memahami informasi dalam lisan maupun tertulis, (b) mampu menyampaikan informasi secara lisan dengan intonasi, lafal, tempo, dan pilihan kata yang tepat, (c) mampu menghasilkan tulisan dengan abahasa yang baik dan benar, dan (d) memiliki kemampuan berkomunikasi dengan siswa dan rekan sejawat dengan bahasa Indonesia yang baik dan benar di kehidupan sehari-hari.

Berdasarkan dari permasalahan mengenai kompetensi guru tersebut dan dirujuk dari teori bahasa Chomsky, guru harus memaksimalkan potensi siswa dalam dua aspek: competence dan performance siswa dalam berbahasa. Untuk mencapai kedua aspek tersebut, guru bahasa Indonesia harus kompetensi bahasa agar performasi bahasa guru dapat menjadi model bagi siswa sehingga peran guru sebagai jembatan pengetahuan bahasa Indonesia kepada siswa dapat terwujud. Artikel ini bertujuan untuk memaparkan kriteria keprofesionalan guru bahasa Indonesia dan upaya yang dapat dilakukan untuk mewujudkan keprofesionalan tersebut.

\section{Kriteria Guru Bahasa Profesional}

\section{Orientasi Teoritis Kriteria Guru Bahasa Indonesia Profesional Menurut Pandangan}

\section{Chomsky}

Chomsky membagi kemampuan berbahasa seseorang menjadi dua, yaitu competence dan performance. Competence dalam teori Chomsky (1965:4) berarti pengetahuan yang dimiliki oleh pemakai bahasa tentang sistematika bahasanya sendiri, sedangkan performance berarti 
penggunaan bahasa bagi pengguna bahasa dalam situasi konkret berdasarkan pengetahuan bahasa yang dimilikinya.

Competence merupakan faktor yang menentukan penguasaan bahasa sesungguhnya. Seharusnya seseorang yang memiliki kompetensi bahasa yang baik juga memiliki performansi bahasa yang baik. Namun, pada kenyataannya tidak demikian. Seseorang yang memiliki kompetensi bahasa yang buruk, bisa saja memiliki performansi bahasa yang baik. Hal ini disebabkan kedua aspek tersebut memiliki mekanisme yang berbeda. Kompetensi bahasa seseorang diperoleh melalui mekanisme akomodatif, sedangkan performansi bahasa seseorang diperoleh melalui mekanisme pelatihan.

Berkaitan dengan kemampuan berbahasa seseorang menurut Chomksy, guru bahasa yang profesional adalah guru yang memiliki kompetensi dan performansi bahasa yang bagus. Kompetensi bahasa yang bagus merupakan kriteria yang penting dimiliki oleh seorang guru bahasa profesional dengan alasan berikut. Pertama, guru bahasa membutuhkan kompetensi yang memadai untuk membekali dirinya dalam mengajarkan bahasa kepada siswa. Kedua, kompetensi bahasa yang dimiliki oleh seorang guru dapat menjadi panduan bagi guru dalam mendeteksi kesalahan berbahasa yang dilakukan siswa di kelas.

Selain kompetensi bahasa, guru juga harus memiliki performansi bahasa yang bagus dengan alasan berikut. Pertama, guru yang memiliki performansi bahasa yang bagus akan mempermudah siswa memahami materi yang disampaikan guru di kelas. Kedua, guru dengan performansi yang bagus dapat menjadi panutan bagi siswa dalam berbahasa yang baik dan benar. Guru yang memiliki performansi bahasa yang bagus ditandai dengan memiliki logika bahasa yang baik sehingga cara tutur yang digunakan guru juga baik. Selain itu, dalam bahasa tulis, guru yang memiliki performansi bahasa yang bagus adalah guru yang memiliki karya tulis. Bahkan, karya tulis tersebut dapat dijadikan materi ajar sehingga siswa dapat membaca karya tulis gurunya secara langsung dan dapat mempererat emosi guru dan siswa di kelas.

\section{Landasan Filosofis Kriteria Guru Bahasa Profesional Menurut Panca Dharma Ki Hajar Dewantara}

Filosofi pendidikan bagi Ki Hajar Dewantara disusun dalam Panca Dharma (Dewantara, 1981), yaitu (1) asas kodrat alam, (2) asas kemerdekaan, (3) asas kebudayaan, (4) asas kebangsaan, dan (5) asas kemanusiaan. Pertama, asas kodrat alam merupakan hakikat dan kedudukan manusia 
sebagai makhluk hidup di dunia, agar senantiasa mengatur dan menempatkan diri dalam hubungan yang harmonis dengan alam dan lingkungan sekitar. Keharmonisan hubungan tersebut akan mendukung tercapainya kesejahteraan. Sebaliknya, jika terjadi pertentangan, maka akan mengarah kepada kehancuran harkat manusia. Kesadaran manusia akan hakikat dan dan kedudukannya di dunia ini, niscaya akan memperkokoh pijakan bagi dirinya dalam berbuat positif demi masa depannya. Sebaliknya, kekeliruan dalam menghadapi dunia ini, akan berujung kepada kesesatan atau kekeliruan yang bersangkutan dalam usaha memperoleh keberhasilan hidup. Hakikatnya manusia sebagai makhluk Tuhan adalah satu dengan kodrat alam (Dewantara, 1981). Manusia merupakan satu kesatuan tak terpisahkan dengan jagad raya ciptaan Tuhan. Manusia berhasil dalam kehidupannya jika mengikuti dan mematuhi kodrat alam yang memiliki banyak hal positif bagi manusia, termasuk penyediaan fasilitas dalam mencapai kemudahan dan keberhasilan hidupnya. Demi kemudahan dan keberhasilan itulah, pendidikan harus dirancang sedemikian rupa dalam kesatuan dan keterpaduannya dengan alam.

Kedua, asas kemerdekaan. Inti dari pandangan ini bahwa manusia dilahirkan ke dunia dalam keadaan bebas merdeka, dalam arti memiliki hak asasi yang bersifat asli untuk hidup dan menyelenggarakan kehidupannya. Hak tersebut melekat pada individu, sehingga tidak ada unsur pemaksaan ataupun penyalahgunaan kekuasaan terhadap orang lain, yang berarti menodai kebebasan individu manusia di muka bumi ini. Kebebasan dan kemerdekaan itu merupakan anugerah dari Tuhan, sehingga tidaklah pantas bila ada pihak tertentu yang ingin mencabutnya. Hak asas kemerdekaan ini dimanfaatkan dengan sebaik-baiknya, dan jangan sampai disalahgunakan semaunya. Dengan asas ini, maka tiap-tiap individu didorong untuk memiliki sikap disiplin dan budi luhur. Dengan adanya sikap-sikap tersebut, maka akan tercipta keteraturan, kesungguhan, dan sikap pantang menyerah dalam menghadapi hidup. Kedisiplinan, pada akhirnya akan menjadi salah satu pilar pendukung kemajuan hidup manusia, baik sebagai individu maupun masyarakat.

Ketiga, asas kebudayaan. Salah satu ciri dari kemajuan individu atau masyarakat dapat dilihat dari corak dan mutu kebudayaan yang berhasil diciptakan dan sekaligus merupakan bagian integral dari realitas kehidupan individu atau masyarakat tertentu. Oleh karena itu, bagi suatu bangsa, sangat penting sekali adanya usaha memelihara dan mengembangkan budaya individu dan masyarakatnya. Budaya akan menjadi salah satu pembentuk identitas bangsa sekaligus pembeda dengan bangsa lain. Kebudayaan suatu bangsa juga merupakan cermin kemajuan dan 
keberhasilan bangsa itu sendiri. Pelestarian dan pengembangan kebudayaan suatu bangsa tidak berarti hanya memelihara dan melindunginya dari pengaruh luar (Dewantara, 1981). Tetapi yang lebih penting adalah, membawa budaya tersebut ke suatu tingkat yang lebih tinggi sesuai dengan tuntutan dan realitas perubahan zaman. Dengan demikian, asas kebudayaan dan pengembangannya ini lebih bersifat dinamis, dan bukan suatu pertahanan yang statis sifatnya. Kebudayaan yang selayaknya dikembangkan dan dipelihara, menurut beliau, mencakup segala hal yang berkaitan dengan kepentingan hidup bangsa itu sendiri, lahir maupun batin.

Keempat, asas kebangsaan. Lazim bahwa setiap bangsa di dunia ini mencintai dan memegang teguh ikatan kenegaraan dan kebangsaannya. Hal ini bukanlah buruk, karena terkandung realitas dan makna persatuan sebagai modal keberhasilan perjuangan bangsa. Tanpa adanya kebanggaan akan identitas kebangsaan, jelas tidak mungkin dicapai keberhasilan dan persatuan, bahkan sebaliknya bisa mengarah kepada pertikaian antar kelompok tertentu atau malah kehancuran bangsa itu sendiri. Akan tetapi, jangan sampai cinta kebangsaan bertentangan dengan prinsip kemanusiaan. Asas kebangsaan harus menampilkan bentuk perbuatan yang nyata, jangan sampai mengarah kepada permusuhan terhadap bangsa lain. Pada lingkup bangsa sendiri, asas tersebut antara lain mendorong rasa persatuan antar kelompok yang ada, juga persatuan dalam kehendak maupun cita-cita untuk mencapai kebahagiaan hidup lahir batin bagi seluruh komponen bangsa.

Kelima, asas kemanusiaan. Seluruh darma, usaha atau pengabdian manusia di tengah perjalanan hidup ini, pada hakikatnya adalah untuk kepentingan harkat dan martabat kemanusiaan. Sebagai layaknya manusia baik secara individual maupun sosial, ia akan berupaya sekuat tenaga agar hajat dan kebutuhan hidup manusiawinya terpenuhi secukupnya. Selama kebutuhan manusiawi tersebut belum terpenuhi, maka perjuangan akan terus berlangsung. Padahal, kebutuhan manusiawi jenis dan ragamnya banyak sekali, termasuk di dalamnya pemenuhan harkat kemanusiaan. Asas kemanusiaan harus ditegakkan di atas prinsip kesucian hati dan rasa cinta kasih terhadap sesama manusia, dan juga kepada semua makhluk Tuhan (Dewantara, 1981). Atas dasar itu, maka jangan sampai ada pihak yang mengatasnamakan kemanusiaan tetapi menyakiti, bahkan menghancurkan hak hidup manusia lain. Prinsip ini sedemikian penting sehingga tidak dapat terpisahkan dari kemanusiaan itu sendiri.

Dalam konteks mewujudkan guru profesional, pandangan filosofis panca dharma Ki Hajar Dewantara dapat dijadikan rujukan terutama dalam sinergitas revolusi mental yang dicetuskan 
oleh pemerintah. Realisasi konkret yang telah dilakukan oleh Ki Hajar Dewantara terutama dalam implementasi pandangan panca dharma di Yayasan Taman Siswa sangat inspiratif untuk dapat dijadikan konsistensi dalam hal profesionalitas guru bahasa Indonesia. Dasar-dasar pendidikan Taman Siswa yang tercermin yakni: (a) Pendidikan adalah usaha kebudayaan yang bermaksud memberikan tuntunan dalam hidup tumbuhnya jiwa raga siswa agar kelak di dalam garis-garis kodrat pribadinya mendapat kemajuan lahir batin menuju arah adab kemanusiaan, (b) Kodrat hidup manusia menunjukkan adanya kekuatan pada manusia sebagai bekal hidupnya yang perlu untuk pemeliharaan dan kemajuan hidupnya. Sehingga tercipta pribadi-pribadi yang dapat mencapai keselamatan dalam hidupnya baik individu maupun masyarakat, (c) Adab kemanusiaan yang mengandung arti keharusan serta kesanggupan manusia untuk menuntut kecerdasan dan keluhuran budi pekerti bagi dirinya serta bersama-sama dengan masyarakat dalam suatu lingkungan alam dan zaman, menimbulkan kebudayaan kebangsaan yang bercorak khusus dan pasti tetap berdasar atas adab kemanusiaan manusia sedunia. Sehingga terwujudlah individu, kemanusiaan, dan kebangsaan yang saling berhubungan karena persamaan dasar, (d) Kebudayaan sebagai buah dan hasil perjuangan manusia terhadap kekuasaan alam dan zaman, membuktikan kesanggupan manusia untuk mengatasi segala kesukaran dalam hidup, guna mencari keselamatan dan kebahagiaan di dalam hidup bersama yang bersifat tertib dan damai, khususnya untuk memudahkan, mempertinggi, dan menghaluskan hidupnya, (e) Kemerdekaan adalah syarat mutlak dalam tiap-tiap segi kehidupan yang berdasarkan keyakinan manusia karena kodratnya sendiri. Hanya dengan terbatasnya pengaruh negatif terhadap kodrat alam itulah akan tercipta suasana aman, sehingga individu maupun masyarakat dapat memelihara, mewujudkan, dan menyempurnakan hidupnya sendiri. Tiap-tiap usaha melawan kodrat alam tersebut akan mempersulit dan menghambat kemajuan hidup siswa, (f) Sebagai usaha kebudayaan, maka tiaptiap satuan pendidikan berkewajiban memelihara dan meneruskan dasar-dasar dan garis-garis hidup yang terdapat dalam tiap-tiap aliran dan kemasyarakatan, untuk mencapai keluhuran hidup menuju ke arah kemanusiaan yang ideal, (g) Pendidikan dan pengajaran rakyat sebagai usaha sadar guna mempertinggi dan menyempurnakan kehidupan rakyat adalah kewajiban negara, yang oleh pemerintah harus dilakukan dengan sebaik-baiknya dengan mengingat dan memperhatikan segala keistimewaan yang sesuai dengan kebatinan masyarakat yang kuat, serta memberikan kesempatan kepada setiap warga negara untuk menuntut kecerdasan budi, kepandaian, dan kecerdasan setinggitingginya menurut kemampuan masing-masing. 
Selanjutnya, Oleh Ki Hajar Dewantara, Panca Dharma sering disebut sebagai aliran, haluan, anjuran, tekad, niat, dan kemauan, supaya semua pihak yang terlibat di dalam kegiatan kependidikan di Taman Siswa mengamalkannya. Selanjutnya, beliau menegaskan:

Bekal-bekal untuk hidup lahir dan batin cukuplah manusia dapatkan dari kodrat alam. Perkembangan jiwa raga haruslah dilindungi kemerdekaan agar tidak menyalahi kodrat hidup manusia dan semua itu menuju ke arah kebudayaan. Kebudayaan yang sejati adalah yang pada lingkaran pertama tercermin dari hidup kebangsaan yang selanjutnya meningkat dan meluas sebagai sifat kemanusiaan. (Dewantara, 1981: 68).

Hal tersebut bertemali dengan revolusi mental yang dicetuskan oleh pemerintah untuk mewujudkan perubahan diri ke arah yang lebih baik. Revolusi mental merupakan upaya berkaitan dengan merubah besar-besaran batin manusia yang mewujud dalam tiga pola yakni pola pikir, pola yakin, dan pola rasa-spiritualitas yang melahirkan prilaku. Tiga pola itu berbasis pada nilai-nilai yang dipatrikan dalam diri seseorang, yaitu: agama, tradisi-budaya dan falsafah bangsa (Siregar, 2016). Eksistensi mental berkarakter seseorang dipengaruhi banyak faktor, antara lain pendidikan, lingkungan, hereditas, dan budaya global. Khusus budaya arus global disatu sisi bermanfaat yakni mempermudah dalam segala bidang kehidupan. Di sisi lain membawa dampak negatif seperti sekularisme, materialisme, liberalisme, hedonisme serta nihilisasi spiritualitas agama.

Dalam UU RI Nomor 20 Tahun 2003 tentang Sisdiknas Bab II Pasal (3) disebutkan bahwa pendidikan nasional berfungsi mengembangkan kemampuan dan membentuk watak serta peradaban bangsa yang bermartabat dalam rangka mencerdaskan kehidupan bangsa, bertujuan untuk berkembangnya potensi peserta didik agar manusia yang beriman dan bertakwa kepada Tuhan Yang Maha Esa, berakhlak mulia, sehat, berilmu, cakap, kreatif, mandiri, dan menjadi warga Negara yang demokratis serta bertanggung jawab. Dari tujuan itu bahwa dikatakan manusia sebagai manusia berjati diri bangsa Indonesia jika seseorang memiliki mental seperti itu. Maka sebagai implikasinya agar tercapai kriteria-kriteria tersebut mau tidak mau harus melalui pendidikan dan pembudayaan di masyarakat. Mental berkaitan dengan batin yang mewujud dalam cara berpikir, cara merasa, dan cara bersikap atau meyakiniyang melahirkan tindakan. Menurut Poerwadarminta (2005) bahwa mentalitas berarti keadaan batin; cara berpikir dan berperasaan, sedangkan revolusi mental pada hakikatnya mengisi mental manusia dengan nilai-nilai luhur (nilai agama, nilai tradisi budaya dan nilai falsafah bangsa) secara besar-besaran sehingga terbentuk karakter baik (good character). 


\section{Upaya Mewujudkan Keprofesionalan Guru Bahasa Indonesia}

Keprofesionalan guru bahasa Indonesia dapat diwujudkan melalui dua hal, yaitu motivasi internal dan motivasi eksternal. Motivasi internal dan eksternal sebagai upaya mewujudkan keprofesionalan guru bahasa Indonesia saling berkaitan. Motivasi internal sangat diperlukan karena motivasi internal akam membuat motivasi eksternal berpengaruh dalam terwujudkan keprofesionalan guru bahasa.

\section{Motivasi Internal}

Usaha seseorang menjadi sosok yang profesional, dalam bidang apapun, termasuk kegiatan belajar sepanjang hayat (lifelong learning). Belajar sepanjang hayat tidak akan terlaksana tanpa kemauan dari dalam diri seseorang. Oleh karena itu, dalam mewujudkan keprofesionalan seseorang dibutuhkan motivasi internal sebelum melakukan upaya-upaya lain yang bersifat eksternal. Motivasi internal akan mendorong seseorang dalam mengembangkan potensi diri setiap waktu.

Potensi diri yang perlu dikembangkan oleh seorang guru bahasa agar mencapai kriteria profesional mencakup dua hal, yaitu kompetensi dan performansi bahasa. Berkaitan dengan dua hal tersebut, guru harus memiliki dorongan kuat dari dalam dirinya untuk meningkatkan kompetensi bahasa dan performansi bahasanya. Motivasi guru dalam meningkatkan kompetensi dan performasi bahasa diawali dengan ketidakpuasannya terhadap kemampuan dan keterampilan bahasanya. Guru dapat mendeteksi kekurangannya sehingga muncul keinginan untuk memperbaiki dan meningkatkan potensi diri.

\section{Motivasi Eksternal}

Selain motivasi internal, guru memerlukan wadah untuk membantunya dalam mengembangkan potensi diri. Oleh karena itu, untuk menjadi guru yang profesional ada upaya yang perlu dilakukan oleh guru, baik atas dasar kemauan sendiri maupun yang terprogram oleh instansi. Berikut dua kegiatan yang dapat dilaksanakan untuk meningkatkan profesionalitas guru.

\section{a. Pelatihan Guru Profesional}

Pelatihan adalah kegiatan yang dilaksanakan untuk menambah wawasan dan kapasitas ilmu pengetahuan guru. Dewi dan Suhartini (2014) menyatakan pelatihan yang berhasil adalah pelatihan yang dapat memberikan nilai tambah pada pengetahuan, sikap dan keterampilan peserta. Pelatihan yang baik adalah pelatihan yang sesuai dengan kebutuhan peserta dan hasilnya 
dapat diterapkan di dunia kerja peserta. Maksudnya, seorang guru harus mempunyai keinginan dan sikap "rasa tidak puas" dengan ilmu pengetahuan yang ia miliki. Para guru harus memahami kekurangan mereka terhadap sesuatu dan berusaha untuk meningkatkan kompetensi yang belum ia penuhi tersebut dengan mengikuti pelatihan.

Menurut Windrawanto (2015:93), model pelatihan yang cocok untuk mengembangkan keprofesionalan guru adalah model school focused: university school partnerships. Metode pelatihan dalam model ini, yaitu lokakarya sekolah, penelitian tindakan, diskusi kelompok, observasi pembelajaran dari praktik yang baik, model berbasis proyek, model pengembangan keterampilan, coaching, mentoring, dan lesson study. Model ini bertujuan sebagai penyegaran dan peningkatan pengetahuan konten dan keterampilan pengajaran berbasis pengetahuan guru.

Dari penjelasan yang dikemukakan oleh Windrawanto tersebut, terdapat beberapa topik pelatihan yang perlu diselenggarakan untuk guru sebagai sebuah program yang berkelanjutan, khususnya untuk guru bahasa Indonesia. Pelatihan guru bahasa Indonesia yang penting untuk dilakukan pada kondisi pendidikan saat ini sebagai berikut.

a. Pelatihan pemulihan materi ajar bahan ajar bahasa Indonesia (menciptakan teks-teks yang berkaitan dengan konteks siswa)

b. Pelatihan pemilihan model pembelajaran, strategi, metode, teknik yang cocok untuk meningkatkan kompetensi berbahasa siswa dan implikasinya c. Pelatihan penggunaan media pembelajaran bahasa Indonesia berbasis teknologi d. Pelatihan melakukan riset di kelas dan menulis karya ilmiah

Beberapa contoh pelatihan tersebut hanya sebagian kecil pelatihan yang semestinya diikuti guru dan banyak pelatihan lain untuk meningkatkan profesionalitas mereka dalam mata pelajaran bahasa Indonesia. Dalam pelaksanaannya, pelatihan dapat menghabiskan waktu lebih dari satu hari. Oleh karena itu, guru diinapkan di satu tempat yang sama dengan sesama peserta pelatihan agar atmosfer belajarnya terjaga; kemudian perlu juga dilakukan simulasi dengan sampel siswa yang sesungguhnya untuk memperkenalkan teknik-teknik mengajar yang inovatif.

Namun, program pelatihan ini masih belum cukup untuk meningkatkan profesionalitas guru. Pelatihan cenderung bersifat pasif; guru tidak bisa saling bertukar pikiran mengenai pengalaman "unik" di kelas kepada orang lain; tidak bisa berkontribusi penuh dalam membagikan ilmu baru tentang pengajaran bahasa Indonesia. Untuk memenuhi kekurangan 
tersebut, perlu adanya kegiatan tambahan untuk meningkatkan profesionalitas guru, seperti seminar yang mewadahi guru untuk mempresentasikan hasil risetnya.

\section{b. Seminar Pendidikan}

Seminar adalah kegiatan pertemuan ilmiah antarpara pendidik, peneliti, ataupun pemerhati dunia pendidikan. Egar (2012:29) menyatakan untuk mencapai predikat guru profesional, salah satu upaya strategis yang harus dilakukan oleh para guru adalah mengikuti seminar. Keikutsertaan guru dalam seminar, menurut Lince (2016:176); Pangestika dan Alfarisa (2015:677); Narjosoeripto (2012:117), merupakan alternatif yang dapat ditempuh guru untuk memperoleh informasi-informasi baru dan berinteraksi dengan sesama kolega untuk membicarakan permasalahan terkini dalam upaya meningkatkan kualitas pendidikan. Oleh karena itu, selain menjadi peserta seminar, guru juga perlu menjadi penyelenggara serta pemakalah dalam seminar agar terlibat dalam kegiatan temu ilmiah (Borang, 2010:248)

Seminar yang dapat diikuti oleh guru bahasa Indonesia untuk meningkatkan kompetensi dan performansi bahasa guru terbagi dua:

a. Seminar linguistik (ilmu bahasa) yang bertujuan untuk meningkatkan pemahaman guru tentang teori ilmu bahasa sehingga memiliki landasan yang kokoh dalam mengajarkan bahasa.

b. Seminar pengajaran bahasa dan sastra Indonesia yang bertujuan untuk meningkatkan wawasan guru tentang cara mengaplikasikan ilmu bahasa dalam pengajaran.

Seminar pendidikan — termasuk pendidikan bahasa — telah banyak dilakukan oleh instansi nseperti universitas, balai bahasa, dan kementrian pendidikan dan kebudayaan. Diharapkan para guru memiliki kemauan untuk mengikuti kegiatan ilmiah tersebut untuk meningkatkan profesionalitas guru; dengan dukungan biaya dari instansi, atau himbauan untuk memanfaatkan uang sertifikasi. 


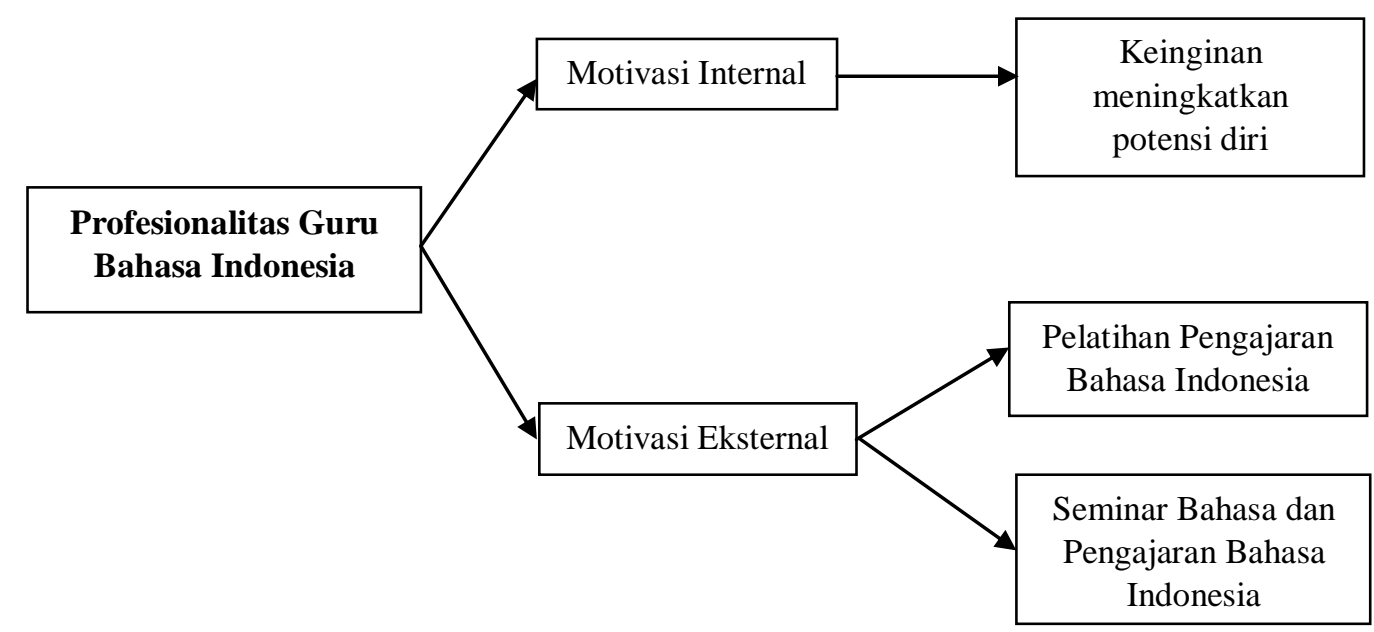

Gambar 2 Upaya dalam Mewujudkan Profesionalisme Guru Bahasa Indonesia

Kedua upaya tersebut-pelatihan dan seminar-memiliki manfaat yang saling terkait. Pelatihan akan menambah keterampilan guru dalam mempersiapkan perangkat pembelajaran, menciptakan trik-trik pembelajaran bahasa yang inovatif, dan meningkatkan semangat belajar guru. Sementara itu, seminar pendidikan akan mendorong guru untuk meningkatkan kompetensi dan performansi bahasanya, menulis karya ilmiah untuk dipresentasikan kepada khalayak, dan mendapat ilmu terkini terkait teori bahasa. Kedua kegiatan tersebut akan menjadi upaya yang jitu untuk meningkatkan keprofesionalan guru jika disertai dengan kemauan guru dalam meningkatkan potensi diri sendiri.

\section{Kesimpulan}

Pada hakikatnya, guru memiliki peran dalam dunia pendidikan sangat esensial. Guru adalah sosok yang secara langsunglangsung berhadapan dengan peserta didik. Oleh karena itu, gurulah yang mengetahui cara mewujudkan pembelajaran yang bermakna dan fungsional untuk siswanya. Dalam pembelajaran bahasa Indonesia, guru bahasa Indonesia sebaiknya mampu mengukur profesionalan mereka; berkeinginan untuk meningkatkan potensi diri; dan terus belajar.

Kegiatan pelatihan dan seminar merupakan dua dari banyak upaya yang bisa diikuti oleh guru bahasa Indonesia untuk meningkatkan keprofesionalannya. Dengan mengikuti kegatan 
seperti pelatihan dan seminar, wawasan guru tentang ilmu bahasa dan cara mengaplikasikannya pengajaran Bahasa Indonesia akan menjadi lebih baik. Oleh karena itu, guru harus memiliki rasa tanggung jawab dalam meningkatkan keprofesionalan mereka dan memiliki rasa ingin terus belajar sepanjang hayat (lifelong learning).

\section{Daftar Rujukan}

Aji, W. N. dan Ngumarno. 2017. Implementasi Kurikulum 2013 Mata Pelajaran Bahasa Indonesia di Kabupaten Klaten. Varia Pendidikan, 29(1):1—8.

Borang, D.S. 2010. Upaya Peningkatkan Kompetensi dan Profesionalisme Guru SMK di Era Sertifikasi. Makalah Disajikan dalam Seminar Internasional "Peran LPTK Dalam Pengembangan Pendidikan Vokasi di Indonesia”, Universitar Ganesha, 29 April-2 Mei.

Chomsky, N. 1965. Aspect of The Theory of Syntax. Massachusetts: The MIT Press.

Dewi, L dan Suhardini, A. L. 2014. Peningkatan Kompetensi Pedagogik Guru Melalui Pelatihan Paikem (Pelatihan Pada Guru Mi Dan Mts Di Kabupaten Cianjur). Edutech, 1(3):1-11.

Egar, N. 2012. Pengembangan Profesionalisme Guru melalui Peningkatan Kompetensi secara Komprehensif. Makalah disajikan dalam Seminar Nasional "Profesionalisme Guru Dalam Perspektif Global", Universitas Bantara Sukoharjo.

http://www.republika.co.id/berita/koran/didaktika/15/05/26/noxxwf2-kompetensi-guru-bahasa$\underline{\text { rendah }}$

Dewantara, Ki Hajar. 1981. Asas-Asas dan Prinsip Taman Siswa. Jakarta: Balai Pustaka.

Firmansyah, M. B. (2018, January 3). MODEL PEMBELAJARAN DISKUSI BERBASIS PERILAKU BERLITERASI UNTUK KETERAMPILAN BERBICARA_BAYU_sept_2017. Retrieved from osf.io/eacnf

Firmansyah, M. B. (2018, January 3).

KompetensiLiterasiMahasiswaDalamPembelajaranMatakuliahSeminarDiProdiPendid ikanBahasaDanSastraIndonesia_Bayu. Retrieved from osf.io/n9xmp

Firmansyah, M. B. (2018, January 3). Social and Political Values in Iwan Fals's Song Collections_bayu. Retrieved from osf.io/ayj8e

Firmansyah, M. B. (2018). Pengembangan Profesionalitas Guru Bahasa Indonesia_M. Bayu Firmansyah_STKIP PGRI Pasuruan Jawa Timur Indonesia.

Firmansyah, M. B. (2018). Evaluasi Pembelajaran Bahasa Berbasis Lingkungan: Perspektif Pendekatan Pragmatik_Mochamad Bayu Firmansyah_STKIP PGRI Pasuruan. 
Firmansyah, M. B. (2018). MODEL PEMBELAJARAN DISKUSI BERBASIS PERILAKU BERLITERASI UNTUK KETERAMPILAN BERBICARA. Jurnal Ilmiah Edukasi \& Sosial, 8(2), 119-125.

Firmansyah, B. (2018). KOMPETENSI LITERASI MAHASISWA DALAM PEMBELAJARAN MATA KULIAH SEMINAR DI PRODI BAHASA DAN SASTRA INDONESIA. Jurnal Ilmiah Edukasi \& Sosial, 8(1), 12-17.

Lince, R. 2015. Strategi Peningkatan Profesionalisme Guru dalam Menghadapi Tantangan di Era Digital. Makalah disajikan dalam Temu Ilmiah Nasional Guru VIII, Universitas Terbuka Convention Center, 26 November.

Narjosoeripto, P. 2012. Profesionalisme Guru dalam Perspektif Global. Makalah disajikan dalam Seminar Nasional "Profesionalisme Guru Dalam Perspektif Global”, Universitas Bantara Sukoharjo.

Pangestika, R.R. dan Alfarisa, F. 2015. Pendidikan Profesi Guru (PPG): Strategi Pengembangan Profesionalitas Guru Dan Peningkatan Mutu Pendidikan Indonesia. Makalah disajikan dalam Seminar Nasional.

Peraturan Pemerintah Republik Indonesia nomor 19 tahun 2005 tentang standar nasional pendidikan. Departemen Pendidikan Nasional Republik Indonesia.

Poerwadarminta, W.J.S. 2005. Kamus Umum Bahasa Indonesia. Jakarta: Balai Pustaka.

Siregar, M. 2016. Paradigma Revolusi Mental Dalam Pembentukan Karakter Bangsa Berbasis Sinergitas Islam Dan Filsafat Pendidikan. Jurnal Pendidikan Agama Islam, 12(2), 161175.

Siswandi, H. J. 2006. Meningkatkan Keterampilan Berkomunikasi Melalui Metode Diskusi Panel dalam Mata Pelajaran Bahasa Indonesia di Sekolah Dasar (Penelitian Tindakan Kelas). Jurnal Pendidikan Penabur, 5(7):24-35.

Wardani, K.D.K.A., Gosong, M., dan Artawan, G. 2013. Sikap Bahasa Siswa terhadap Bahasa Indonesia: Studi Kasus di SMA Negeri 1 Singaraja, E-jurnal Program Pascasarjana Universitas Pendidikan Ganesha Program Studi Pendidikan Bahasa dan Sastra Indonesia.

Windrawanto, Y. 2015. Pelatihan dalam Rangka Pengembangan Keprofesian Berkelanjutan Guru: Suatu Tinjauan Literatur. Satya Widya, 31(2):90-101 